\title{
COMPARATIVE IZOD IMPACT TESTS OF EPOXY COMPOSITE REINFORCED WITH CURAUA FIBERS AND FIBERGLASS*
}

\section{Resumo}

Natália de Oliveira Roque Maciel $^{1}$

Carolina Gomes Dias Ribeiro ${ }^{2}$ Jordana Barreto Ferreira ${ }^{2}$ Janaina da Silva Vieira ${ }^{2}$ Frederico Muylaert Margem ${ }^{3}$ Carlos Maurício Fontes Vieira ${ }^{4}$ Sérgio Neves Monteiro

Nos últimos anos, especialmente fibras naturais extraídos de plantas lignocelulósico, ganharam atenção devido ao seu desempenho como engenharia de reforço compósito polímero. Por exemplo, as fibras lignocelulósicas extraídos a partir das folhas da planta curauá (Ananas acutifolius) exibir um potencial de reforço devido à sua relativamente alta resistência. As fibras, entre 0 a $30 \%$ em volume de, foram misturados com resina de poliéster sob pressão num molde metálico, e curada à temperatura ambiente durante 24 horas. Este trabalho procura avaliar a resistência ao impacto deste tipo de matriz de epóxi fibra de reforço. A resistência ao impacto aumentado substancialmente com a quantidade relativa de fibras de curauá reforço do compósito. Este desempenho foi associada com a resistência imposta pelas fibras e o comportamento de propagação da fissura

Palavras-chave: Fibras de curaua; Ensaio de impacto izod; Matriz epoxy.

\section{ENSAIO IMPACTO IZOD COMPARATIVO ENTRE COMPÓSITOS EPOXY REFORÇADO COM FIBRAS DE CURAUÁ E FIBRA DE VIDRO}

\section{Abstract}

In recent years natural fibers, especially lignocellulosic extracted from plants, have gained attention owing to their engineering performance as polymer composite reinforcement. For instance, the lignocellulosic fibers extracted from the leaves of the curaua plant (Ananas erectifolius) display a reinforcement potential owing to their relatively high strength. The fibers, between 0 to $30 \%$ in volume, were mixed with polyester resin under pressure in a metallic mold, and cured at room temperature for 24 hours. This work attempts to evaluate the impact resistance of this type of fiber reinforcing epoxy matrix. The impact resistance increased substantially with the relative amount of curaua fiber reinforcing the composite. This performance was associated with the resistance imposed by the fibers and the crack propagation behavior.

Keywords: Curaua fibers; Impacto izod tests; Notch toughness; Epoxy matrix.

1 Graduating in industrial Engineering, Master, Student, LAMAV, State University of the Northern Rio de Janeiro/UENF, Campos dos Goytacazes, Rio de Janeiro, Brazil.

2 Graduating in Metallurgical and Materials Engineering, Student, LAMAV, State University of the Northern Rio de Janeiro/UENF, Campos dos Goytacazes, Rio de Janeiro, Brazil.

3 Doctor in Materials Engineering, Doctor, Assistant teacher, Science center in engineering, Redentor college, Itaperuna, Rio de Janeiro, Brazil.

4 Doctor in Mechanical engineering, Doctor, Professor, Advanced Materials Laboratory, State University of the Northe Fluminense/UENF, Campos dos Goytacazes, Rio de Janeiro, Brazil.

$5 \mathrm{PhD}$ in Materials Engineering, Emeritus Professor, Department of Materials IME, Rio de Janeiro, Braziil 


\section{INTRODUCTION}

Natural fibers, especially those lignocellulosic obtained from plants, offer economical environmental and technical advantages in comparison to synthetic fibers for application as the reinforcement of polymeric composites. For the industry, low cost is certainly an important incentive associated with the use of lignocellulosic fibers that usually have a commercial price around five times lower than that of glass fiber, the cheapest among the synthetic fibers.

Environmental issues are, additionally gaining attention owing to worldwide problems related to climate changes and pollution. This is nowadays a major advantage for the natural fibers that are renewable, biodegradable and recyclable. By contrast to glass fiber composites that cannot be recovered, natural fiber composites can be completely burnt to produce energy. Moreover, lignocellulosic fibers are neutral with respect to $\mathrm{CO} 2$ emission, the main responsible for global warming.

In these works, Izod impact tests with notched and fixed specimens resulted in absorbed energy values lower than $60 \mathrm{~J} / \mathrm{m}$ for all fibers investigated as polypropylene composite reinforcement. Recent works on the impact resistance of thermoset polymer composites reinforced with long and aligned lignocellulosic fibers [10-15], revealed a much higher value for the impact energy. In particular, a polyester composite reinforced with $40 \%$ of curaua fiber reached $170 \mathrm{~J} / \mathrm{m}$ [11], which is more than three times the maximum obtained by any short-cut and randomly oriented lignocellulosic fiber composites [9]. This remarkable result served as motivation for a work to confirm it with a different impact method, the Charpy test.

\section{MATERIALS AND METHODS}

\subsection{Curaua Fibers}

The curaua fiber is obtained from a plant with same name, a bromeliad (Ananas Erectifolius), the same pineapple family and was purchased from "Amazon Paper", a company that sells natural lignocellulosic fibers grown in the Northern Region of Brazil, specifically in the Amazon. The typical aspect of curaua plant and curaua fiber are shown in Figure 1.

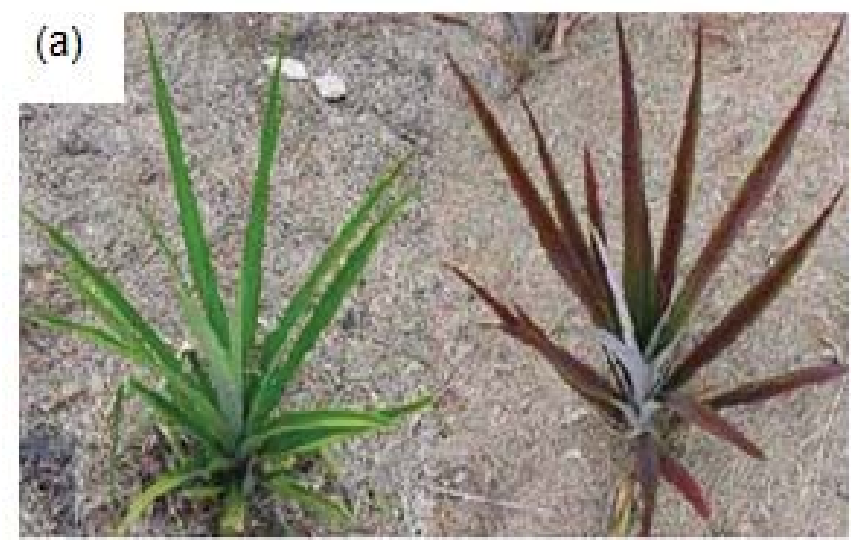

(b)

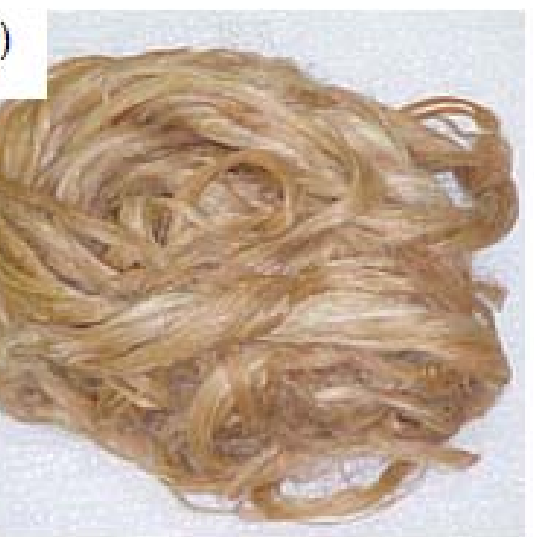

Figure 1: (a) Curaua Plant and (b) Curaua fiber processed and ready to be used as reinforcement in composite

These fibers were used without any surface treatment, only a fast cleaning and air drying. 
Hundred fibers were chosen to measure the length and diameter through a ruler and a profile projector respectively, and with the results obtained were calculated the average length (L) and the average diameter (d). Figure 2 is a histogram measurementswhere it was possible to obtain $L=442 \mathrm{~mm}$ and $\mathrm{d}=$ approximately $0.17 \mathrm{~mm}$ [7]. The fibers were individually weighed and through calculating a geometric cylinder, afforded the density of the fiberglass, which was approximately $0.92 \mathrm{~g} / \mathrm{cm}^{3}$.
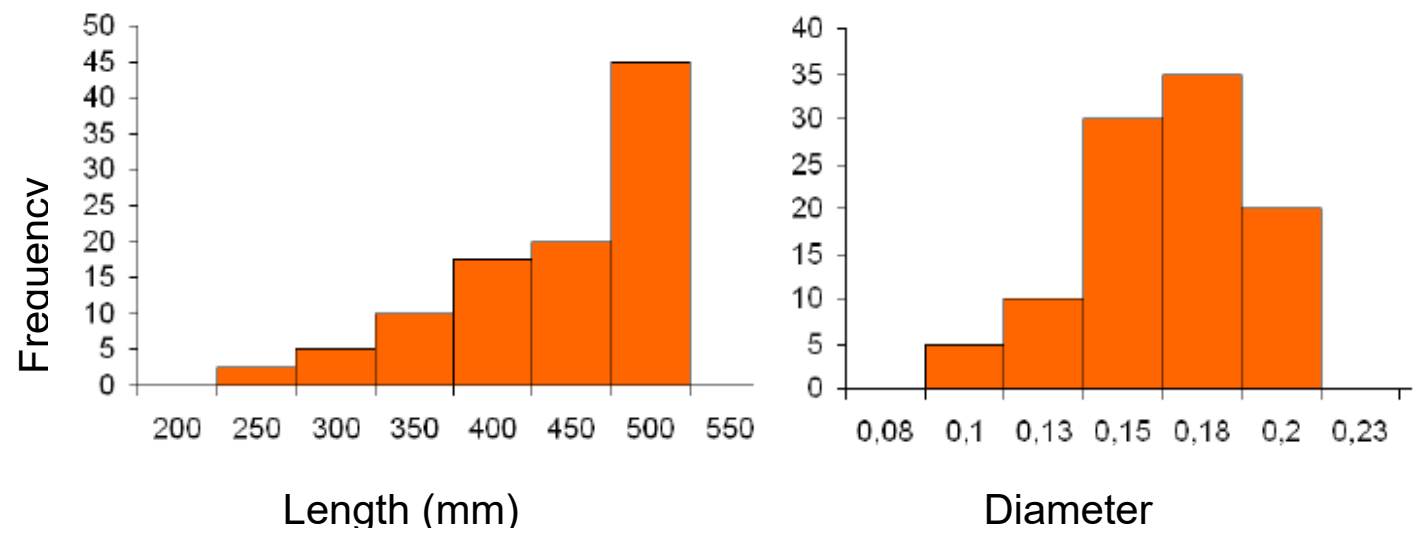

Figure 2: Histogram for measures distribution of length and diameter of fiber curaua

\subsection{Fiberglass}

The fiberglasses were purchased from Glass Company. This company provides repairs on vehicles and surfboards using as raw material the fiberglass. According to the manufacturer, the fiberglass is E-type with a density of approximately $2.6 \mathrm{~g} / \mathrm{cm}^{3}$ and a mean diameter in the range from 8 to $14 \mathrm{~mm}$. Figure 3 shows the glass fiber used in this work, the same is in the form of wire, known as roving.

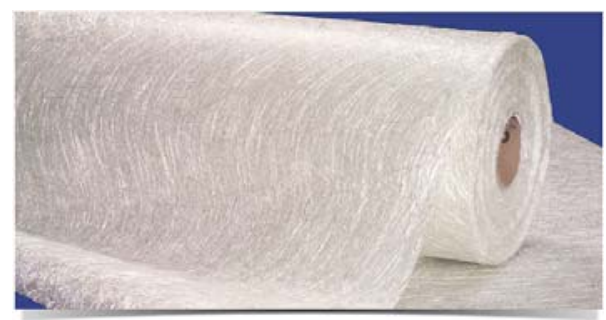

Figure 3: Fiberglass shaped in wire (roving) used for the production of composite

\subsection{Specimens}

According to the ASTM D 256 norm, there are significant differences between both tests, Charpy and Izod [15] that could lead to distinct results. These differences are shown in Fig.4. 


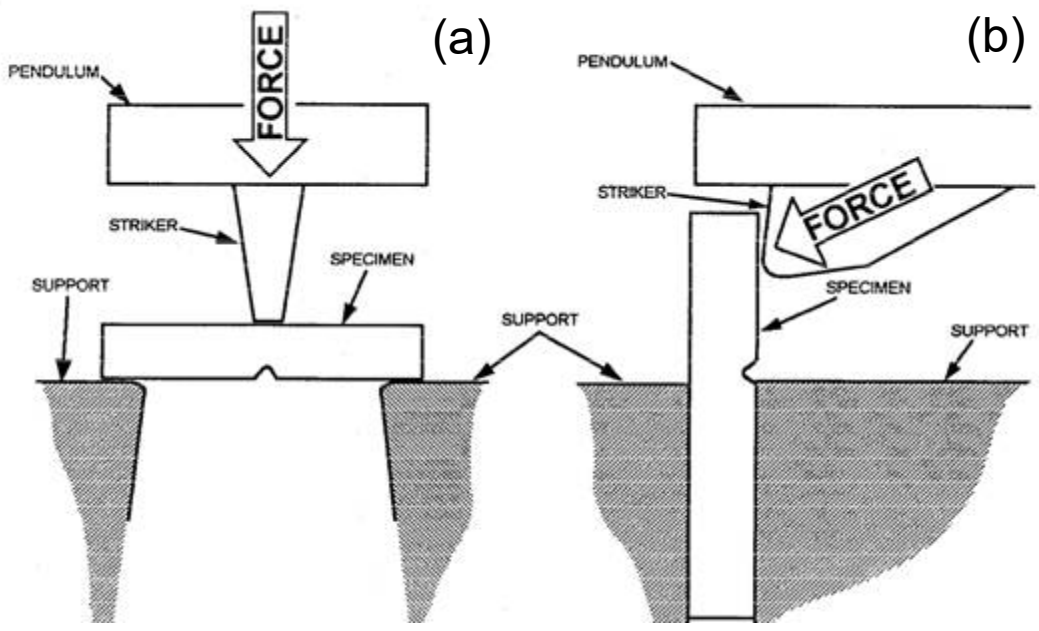

(b)

Figure 4. The Charpy (a) and the Izod (b) impact test methods.

Natural fibers, especially those lignocellulosic obtained from plants, offer economical This figure reveals that the Charpy specimen, with a minimum length of $124 \mathrm{~mm}$, is free-standing on the support during the impact, Fig. 4 (a), with a hammer, which strikes exactly at the opposite side of the notch. By contrast, the Izod specimen has a maximum length of $63 \mathrm{~mm}$ and is fixed to the support during the impact, Fig. 4 (b), which strikes at a point $22 \mathrm{~mm}$ away from the notch. In practice, the Izod test simulates better the actual situation of a component fixed into a system, which is hit at a point away from a stress raiser like a grove or a flange.

\section{RESULTS E DISCUSSION}

The variation of the Izod impact energy with the amount of curaua fiber in the polyester composite is shown in Fig. 5.

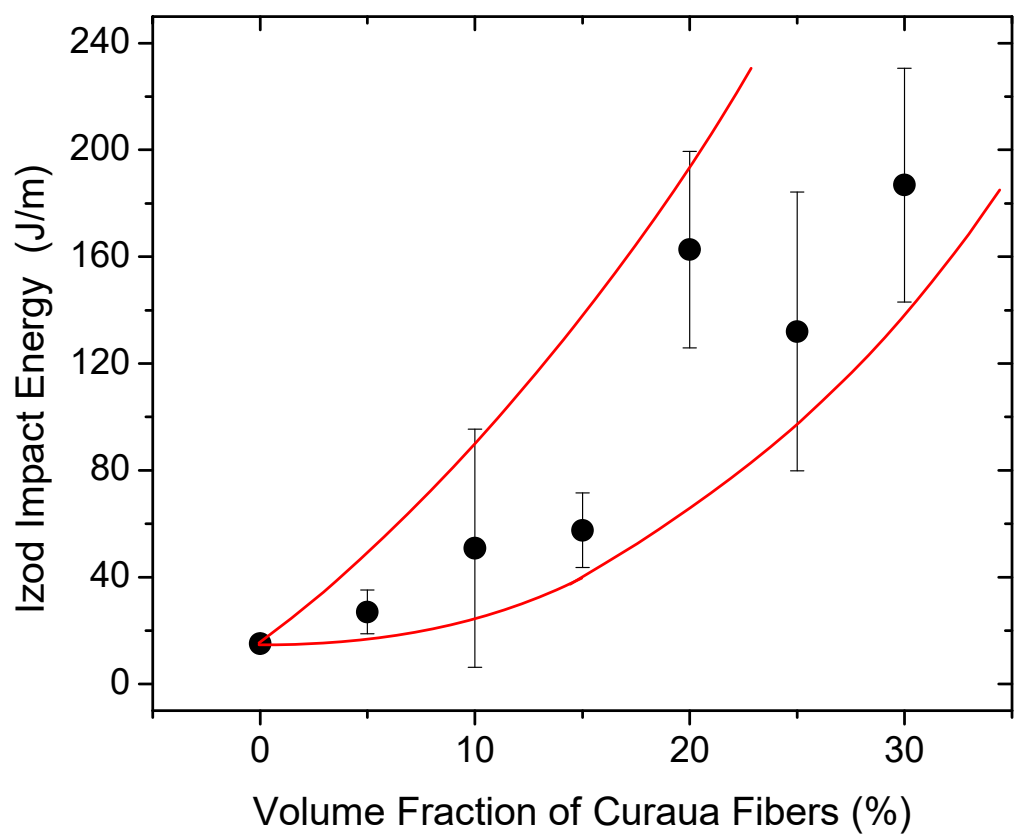

Figure 5. Izod impact energy as a function of the amount of curaua fibers. 
In this figure it should be noticed that the curaua fiber incorporation into the polyester matrix significantly improves the impact toughness of the composite. Within the standard deviation, this improvement can be considered as an exponential function with respect to the amount of curaua fiber up to $30 \%$. The relatively high dispersion of values, given by the error bars associated with the higher fiber percentage points in Fig. 5 is a well known non-uniform characteristic of the lignocellulosic fibers [2]. The values shown in this figure are consistent with results reported in the literature. The reinforcement of a polymeric matrix with both synthetic [18] and natural $[8,19]$ fibers increases the impact toughness of the composite. Table I compares values of impact toughness of polymeric composites with different natural fibers.

In this work, using long and aligned curaua fibers, the impact toughness is significantly higher than the values reported for polypropylene composites reinforced with $50 \%$ of short cut and randomly oriented lignocellulosic fibers. The greater impact resistance of the polyester in comparison with the polypropylene matrix could be one reason for the superior performance of the present result. However, there are other important factors related to the impact fracture characteristic of polymeric reinforced with long and aligned natural fibers.

Table I. Impact toughness of polymeric composites reinforced with natural fibers.

\begin{tabular}{|c|c|c|c|c|}
\hline Composite & $\begin{array}{l}\text { Amount of } \\
\text { Fiber (\%) }\end{array}$ & $\begin{array}{c}\text { Fiber Condition } \\
\text { in the } \\
\text { Composite }\end{array}$ & $\begin{array}{c}\text { Izod Impact } \\
\text { Toughness (J/m) }\end{array}$ & Reference \\
\hline Jute/Polypropylene & 50 & $\begin{array}{c}\text { Short-cut } \\
\text { randomly oriented }\end{array}$ & 39 & [8] \\
\hline Sisal/ Polypropylene & 50 & $\begin{array}{l}\text { Short-cut } \\
\text { randomly oriented }\end{array}$ & 51 & [8] \\
\hline Flax/ Polypropylene & 50 & $\begin{array}{l}\text { Short-cut } \\
\text { randomly oriented }\end{array}$ & 38 & [8] \\
\hline Wood/ Polypropylene & 50 & $\begin{array}{l}\text { Short-cut } \\
\text { randomly oriented }\end{array}$ & 28 & [8] \\
\hline Curaua/ Polypropylene & 50 & $\begin{array}{l}\text { Short-cut } \\
\text { randomly oriented }\end{array}$ & 54 & [8] \\
\hline Coir/ Polypropylene & 50 & $\begin{array}{l}\text { Short-cut } \\
\text { randomly oriented }\end{array}$ & 46 & [8] \\
\hline Coir/polyester & 40 & Long and aligned & 121 & [20] \\
\hline Curaua/polyester & 30 & Long and aligned & 190 & this work \\
\hline
\end{tabular}

The relatively low interface strength between a hydrophilic natural fiber and a hydrophobic polymeric matrix contributes to an ineffective load transfer from the matrix to a longer fiber. This results in relatively greater fracture surface and higher impact energy needed for the rupture [21]. Another factor is the flexural compliance of a long fiber during the impact test, which will be further discussed.

The incorporation of long and aligned curaua fibers results in a marked change with respect to pure polyester $(0 \%$ fiber) in which a totally transversal rupture occurs. Even with $10 \%$ of fiber, the rupture is no longer completely transversal. This indicates that the cracks nucleated at the notch will initially propagate transversally through the polyester matrix, as expected in a monolithic polymer. However, when the crack front reaches a fiber, the rupture will proceed through the interface. As a consequence, after the Izod hammer hit the specimen, some long fibers will be pulled out from the 
matrix but, owing to their compliance, will not break but simply bend. In fact, for amounts of fiber above $10 \%$, the specimens are not separated at all. For these amounts of long curaua fibers, part of the specimen was bent enough to allow the hammer to continue its trajectory without carrying away the top part of the specimen, as expected in a lzod test. The value of the impact toughness in this case cannot be compared with others in which the specimen is totally split apart. Anyway, the fact that a specimen is not completely separated in two parts underestimates the impact toughness. In other words, had all the fibers been broken, the adsorbed impact energy would be higher.

\section{CONCLUSIONS}

- Composites of aligned curaua fibers reinforcing a polyester matrix display a significant increase in the toughness, measures by the Izod impact test, as a function of the amount of the fiber.

- Most of this increase in toughness is apparently due to the low fiber/polyester matrix interfacial shear stress. This results in a higher absorbed energy as a consequence of a longitudinal propagation of the cracks throughout the interface, which generates larger rupture areas, as compared to a transversal fracture.

- Amounts of curaua fibers above $10 \%$ are associated with incomplete rupture of the specimen owing to the bend flexibility, i.e., flexural compliance, of the curaua fibers.

\section{Acknowledgements}

The authors thank the support to this investigation by the Brazilian agencies: CNPq, CAPES, FAPERJ and TECNORTE/FENORTE.

\section{REFERENCES}

1 SATYANARAYANA, K.G.; GUIMARÂES, J.L.; WYPYCH, F. Studies on lignocellulosic of Brazil. Part I: Source, production, morphology, properties and applications. Composites: Part A, v.38, p. 1964-1709, 2007.

2 SATYANARAYANA, K.G.; SUKUMARAN, K.; KULKARNI, A.G.; PILLAI, S.G.K.; ROHATGI, P.K. Fabrication and properties of natural fibre-reinforced polyester composites. Composites. V. 17, p. 329-274, 1999.

3 BLEDZKI, A.K.; GASSAN, J. Composites reinforced with cellulose-based fibers. Prog. Polym. Sci, v.24, p. 221-274, 1999.

4 PEIJS, T. Natural Fibers Based Composites. Mater. Technol. v.15, p. 281-285, 2000

5 WAMBUA P.; IVENS. I.; VERPOEST, I. Natural fibers: can they replace glass and fiber reinforced plastic?" Composites Science and Technology, v. 63, p. 1259-1264, 2003.

6 MOHANTY, A.K.; MISRA, M.; DRZAL, L.T. Sustainable biocomposites from renewable resources: Opportunities and challenges in the green materials world. J. Polym. Environ. v. 10, p. 19-26, 2002.

7 MONTEIRO, S.N.; LOPES, F.P.D.; FERREIRA, A.S.; NASCIMENTO, D.C.O. Natural fiber polymer matrix composites: Cheaper tougher and environmentally friendly. JOM, v. 61, p. 17-22, jan. 2009.

8 LEÃO, A.L.; TAN, I.H.; CARASCHI, J.C. Curaua fiber - A tropical natural fiber from Amazon - Potential and applications in composites. In: INTERNATIONAL 
CONFERENCE ON ADVANCED COMPOSITES, Hurghada, Egito, Maio, 1998, p. 557564.

9 MONTEIRO, S.N.; FERREIRA, A.S.; LOPES, F.P.D. Izod impact energy of polyester matrix composites reinforced with aligned curaua fibers. In: Mineral, Metals \& Materials Characterization Symposium - TMS Conference, San Francisco, EUA, March 2009. p. $1-8$.

10 YUE, C.Y.; LOOI, H.C; QUEK, M.Y. Assessment of Fiber-Matrix Adhesion and Interfacial Properties Using the Pullout Test. Int. J. Adhesion and Adhesives, v. 15, 1995, p. 73-80. 